\title{
Open Data's Role in Social Innovation Initiatives to Fight COVID-19
}

\author{
Fernando Almeida ${ }^{1}$
}

Submitted: 23.01.2021. Accepted: 13.06.2021

\section{Abstract}

Purpose: This study aims to explore the role open data assumes in social innovation initiatives that combat the effects of Covid-19, in which quantitative information about these projects is complemented with the analysis of open data innovation capabilities.

Methodology: A mixed methods approach is adopted. Initially, quantitative data regarding the number of innovative projects is extracted from the OPSI framework. Then, in a second phase, qualitative data from each project is explored to explore the open data innovation capabilities offered by each initiative.

Results: The results reveal that most social innovation initiatives focus on the area of data visualization dashboards and open datasets. However, some projects address other areas, e.g. hackathons, service availability, and tourism information.

Implications: Covid-19 profoundly affects the lives of people and businesses, and open data can assume a determinant role in mitigating these effects and improve information transparency and collaboration between public and private entities.

Originality/Value: This study is relevant for the establishment of supportive public policies that promote the emergence of open-data-driven initiatives to mitigate the effects of Covid-19 in several areas such as the economy, education, and leisure.

Keywords: Covid-19, open data, social innovation, entrepreneurship, technology.

\section{JEL: 031, 035, L26}

Gaya Higher Institute (ISPGAYA) \& INESC TEC, Porto, Portugal, Av. dos Descobrimentos, 3334400-103 Santa Marinha - V.N.Gaia; e-mail: almd@fe.up.pt; https://orcid.org/0000-0002-6758-4843. 


\section{Introduction}

The rapid development of information and communication technologies and the democratization of access to technological platforms and structures have radically changed the paradigms of information creation and transformation (Chen et al., 2015). Furthermore, this has contributed to the construction of community approaches to innovative solutions to social problems (Hossain, 2015). Open data have become important in the development of information and communication technologies. The benefits of open data lie not only in the technological dimension but also reside in possible economic and social benefits. The economy can benefit from easier access to information, content, and knowledge, thus contributing to the implementation of innovative services and the creation of new business models (Fell, 2019). Social welfare can also be improved because society benefits from more transparent and accessible information. According to Ruijer and Meijer (2020), open data foster collaboration, participation, and social innovation. The potential of reusing open data is inseparable from the ability to work with it through automatic mechanisms, thus integrating it into open access platforms. The material benefits of open data apply to various sectors of activity, with various groups of individuals and organizations able to benefit from this information availability.

The role of technology in the development of entrepreneurial activity is unequivocal. Currently, the concepts of social entrepreneurship and sustainable development intersect, and social entrepreneurs are perceived as agents of change (Johnson and Schaltegger, 2019). Today, the need for adaptation and learning is largely justified by globalization and uncertainty. The problems are huge and multidimensional, covering both economic, environmental, and social dimensions. As Musa (2019) argues, the answer to these challenges is only achieved through a community approach to combat these problems, and social economy organizations are positioned to become the pillars whose mission is based on the fulfillment of community solidarity relations among diverse surrounding environments.

These challenges were further exaggerated by the emergence of the Covid-19 pandemic. As Roper and Turner (2020) indicate that in this unique moment of global crisis initiated by the coronavirus pandemic, what is becoming increasingly evident is the importance of science and innovation. We face an unprecedented and borderless crisis that has emerged in the space of a few months. While a significant part of the world's population is isolated in their homes in an attempt to contain the advance of the disease, the 
extent of humanitarian, social, and economic repercussions remains unpredictable. Governments and organizations from various sectors face unprecedented and unusual challenges. In these scenarios, impacts that are still difficult to quantify can affect people and businesses.

Government entities, companies, and civil society face an unprecedented solidarity effort to jointly seek innovative solutions in hope of mitigating the effects of Covid-19. These initiatives are very diverse and involve many stakeholders. Knowing the characteristics and potential of these projects is of great importance for the establishment of public policies that can enhance the emergence of initiatives that would bind the community and offer a strong social impact. In this sense, this concise article aims to explore the role of open data in initiatives aiming to fight the effects of Covid-19. To this end, I employ information from the Observatory of Public Sector Innovation (OPSI) provided by the Organization for Economic Co-operation and Development (OECD) to quantitatively identify relevant projects, and I use the framework proposed by Eckartz et al. (2016) to qualitatively explore the open data innovation capabilities of these projects. Both approaches are combined using the mixed methods approach to understand the big data phenomenon in these innovative solutions.

The remainder of this manuscript is organized as follows. I initially perform a brief analysis of the role of social and innovation entrepreneurship. After that, I present the methodology supported in mixed methods. The results are then presented and discussed considering their relevance and existing literature in the area. Finally, I formulate conclusions and suggestions for future research.

\section{Literature Review}

Covid-19 has caused the economic and social structures of many countries to suffer major impacts (Nicola et al., 2020; Pawar, 2020; Polyakova et al., 2020). New strategies emerged to find solutions, and social entrepreneurship presents itself as a community response, coming from all parts of society. A significant number of projects supported by the concept of social entrepreneurship have emerged that aim to mitigate the effects of Covid-19 in a wide range of activity sectors. Many of these projects involve diverse public, private, and civil society partners working together to find technologically innovative solutions with a strong social impact. The central concern of these initiatives is the availability of open data for the community to enable other partners' involvement in these initiatives, but also to allow the research of the initiatives by the scientific community. 
The concepts of social entrepreneurship and sustainable development are interconnected, and social entrepreneurs are perceived as change agents who use business and personal resources to provide systemic solutions to social and environmental problems (Saebi et al., 2019). Social entrepreneurship has become a fundamental part of today's societies due to the increase in social exclusion and the aging of the population, but also due to the budgetary difficulties that have led many governments to reduce their participation in social services. Ngatse-Ipangui and Dassah (2019) argue that one of the major objectives of social entrepreneurship is the involvement of local communities in a set of activities that improve their well-being and reduce the risk of harmful behavior, particularly among the most disadvantaged.

Social entrepreneurship is a current theme among political and business classes. The groups tried to find new answers to old problems but with new outlines such as poverty, social exclusion, unemployment, and social protection. According to Johnson and Schaltegger (2019), social entrepreneurship uses innovation in resources, exploits opportunities, and sustainably satisfies social needs. For Javed et al. (2019), social entrepreneurship is the name given to a set of entrepreneurial actions that aim to improve society through which sustainable measures are implemented in communities to reconcile technological advances and other progress with a healthy environment and good living conditions for the population. Montgomery et al. (2012) emphasize that social entrepreneurship is mainly driven by community values, which they consider a collective rather than an individual benefit. Accordingly, and in a general sense, social entrepreneurship can be understood as the application of business processes but with social purposes.

The causes of the growing interest in this phenomenon are diverse and interconnected. Among economic, social, and political changes, Bornstein (2007) distinguishes two aspects in the development that has occurred: the development of problems that require innovative approaches in their resolution and the development that creates opportunities for these problems to be solved. Considering this line of reasoning, the growing inequality in wealth distribution and the concerns with the environment have sustained the growth of social entrepreneurship. However, technological evolution has also allowed the emergence of alternative approaches to deal with these social, economic, and environmental issues (Ismail et al., 2012).

Social entrepreneurs are agents of change in the social sector since they foster social improvement, create social value, treat the causes of social problems and not just the symptoms by reducing needs (Gandhi and Raina, 2018). Therefore, social entrepreneurs are individuals who have innovative solutions to social problems. According to Nga 
et al. (2018), social entrepreneurs are persevering and ambitious as they seek solutions to social problems that governments fail to solve. Finally, Parente et al. (2013) characterize social entrepreneurs as individuals who have a social mission and not that of wealth creation, namely the process of creating social value through business management but without taking profit from this activity.

Besides the common characteristics of the entrepreneurial entrepreneur and the social entrepreneur, there are remarkable differences between the two profiles. Social entrepreneurship is collective because it involves the whole community in a common effort of participation, integration, and development (Petrella and Richez-Battesti, 2014). It produces goods and services for society to ensure more dignified living conditions (Ormiston and Seymour, 2011). However, what social entrepreneurs seek is not the success of sales but the success of social impact.

Innovation is a necessity of the entrepreneurship process from which humanity has transformed its relationship with reality. Innovation is characterized by authors like Dawson and Andriopoulos (2017) and Goffin and Mitchell (2016) as the action or act of innovating, namely that of modifying old customs, processes, or legislation. In this sense, the act of innovating means the need to create different paths or strategies to the usual means to attract a certain objective.

Social innovation is a segment of innovation that looks at new ideas and designs on the market that meet social needs (Grimm et al., 2013). The European Commission (2021) defines social innovation as "developing new ideas, services and models to better address social issues. It invites input from public and private actors, including civil society, to improve social services." The created value should primarily benefit society as a whole and not specific individuals. Social entrepreneurship uses social innovation to deliver distinctive solutions in the marketplace. It encompasses not only interconnected opportunities and needs but also activities whose ambiguity extends from non-profit organizations to social responsibility operations with associated profits (Bittencourt et al., 2017).

Two dimensions meet in the concept of social innovation. Innovation encompasses the capacity to create and implement new ideas and create value, and the social dimension refers to the type of value that the innovation itself intends to allocate. According to Tello-Rozas (2016), this is a value that is not directed to profit but to quality of life, solidarity, and well-being. The relationship between entrepreneurship and innovation is a process through which entrepreneurs convert opportunities into feasible market ideas. In fact - as Neto et al. (2019) state - the creation of a good idea 
is not enough, as its realization is fundamental for the success of innovation, which is only achieved through perseverance and dedication. Thus, implementation becomes the key function in the entrepreneurial process.

Social innovation as a concept proves difficult to implement. The adoption of social innovation requires the dissatisfaction of society with its current practices and the realization that innovation can satisfy a basic need. Muñiz-Avila et al. (2016) state that the primary objective of social entities is the creation of social value for the community they serve through innovative business approaches. Nicholls et al. (2015) complement this vision by stating that social innovation can be incorporated into a product, service, process, or business model itself.

Social companies demand creative and innovative solutions to solve social problems. Witkamp et al. (2011) state that these companies need a strategic management method that increases their ability to pursue social missions, improves efficiency and effectiveness, and at the same time, maximizes their ability to generate innovative ideas for sustainable ventures in a competitive environment. Then it becomes apparent that social enterprises can benefit from the transfer of strategies developed by for-profit organizations. This vision is supported by Diepenmaat et al. (2020) who mention that the adoption of entrepreneurial practices and social innovation, including the customization of services and customer relations, offers the potential for sustainability and growth.

Finally, we should look at the impact of social innovation. The European Commission considers that social innovation will have a key role in addressing several challenges in areas such as increasing the effectiveness and efficiency in responding to social challenges, in the lifelong learning processes of people, in supporting the most disadvantaged communities, and in establishing innovative partnerships between government entities and private resources (EC, 2021). In the period affected by the pandemic of Covid-19, these challenges become even more relevant and require responses from the entire community.

\section{Methods and Materials}

This study uses a mixed-method approach to explore the role of open data in initiatives that combat the effects of the Covid-19 pandemic. Mixed-method research combines qualitative and quantitative research methods and aims to generalize qualitative results, deepen the understanding of quantitative results, or corroborate qualitative 
or quantitative results. This study applies the sequential explanatory design as proposed by Creswell and Clark (2017). In this approach, the first phase of research focuses on a quantitative study, followed by a qualitative phase. This approach allows for the interpretation of previously identified quantitative results. According to Almeida (2018), this approach becomes appropriate when we explore an emerging phenomenon in which available quantitative data are very scarce or incomplete.

Figure 1 visually presents the phases of the adopted methodology. Initially, quantitative data was obtained from the OPSI framework. With this, we received an overview of the geographic distribution and areas of incidence of each project. However, this information was incomplete since it disallows us to understand the specific characteristics and particularities of each of these initiatives. In this sense, in the second phase, each project was explored and analyzed by considering the framework of open data innovation capabilities provided by Eckartz et al. (2016). This gathering process was conducted on December 7-22, 2020.

Figure 1. Phases of the mixed methods process

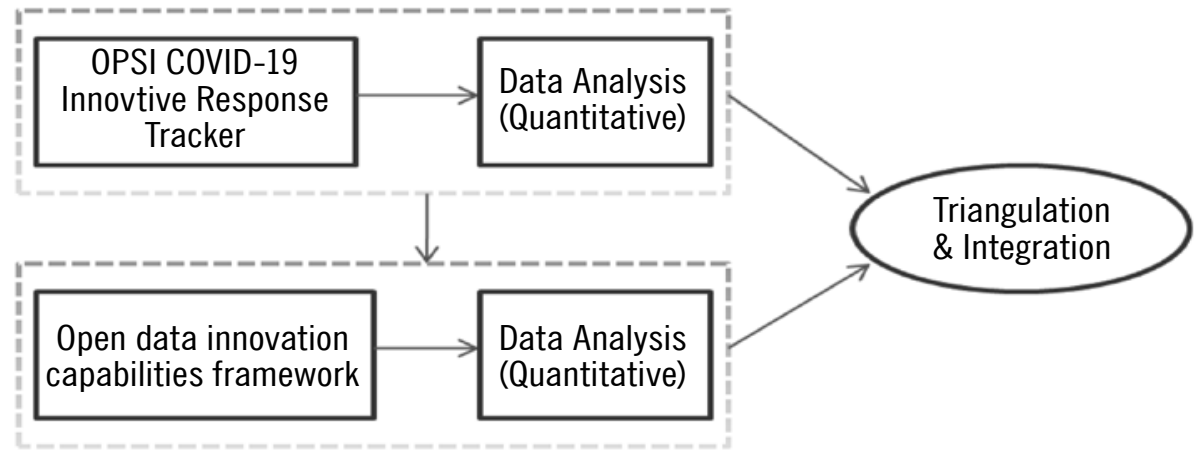

Source: own elaboration.

Finally, I conducted two interviews with policymakers in one European country (Portugal) to understand the importance of open data in the implementation of these projects. These interviews happened between March 30 and April 19, 2021. I interviewed the Chief Information Officer (CIO) of the data dashboard on Covid-19 in Portugal and the management of the innovation department of the Shared Services Center in Portugal. These two perspectives were complementary and allowed me to explore the role of open data in the operational and strategic dimensions. In the first interview, I asked the following questions: Q1: How did this initiative come about? Q2. What is the role of open data in this initiative? Q3. What synergies existed with other partners? Q4: What is the social relevance of this initiative? In the second interview, I asked the following 
questions: Q1. What is the role of government entities in supporting social innovation initiatives to combat Covid-19? Q2. What is the role of open data in government digitization? Q3. What are the impacts of open data on social innovation projects?

The OPSI framework was developed by the OECD between January 2016 and January 2019 funded under H2020-EU.3.6. to understand the role of public sector innovation in addressing emerging social challenges. The OPSI framework identifies worldwide projects that adopt innovative approaches and innovative governance models to support economic growth and social welfare (OECD, 2019). In March 2020, this framework was extended to include the OPSI Covid-19 Innovative Response Tracker. The innovative responses to OPSI OVID-19 are characterized by five dimensions: (i) countries; (ii) level of government; (iii) addressed issues; (iv) response tags; and (v) badges. The "badges" dimension identifies the projects supported in open data.

The framework proposed by Eckartz et al. (2016) allows scholars to explore the open data innovation capabilities according to a multidimensional approach consists of three perspectives: (i) IT capabilities; (ii) organizational capabilities; and (iii) people capabilities. Table 1 explores the factors that can be found in these three categories. In the IT capabilities dimension, we find elements related to technological infrastructure, data management, data governance, security, or system integration. In the organizational capabilities dimension, we find elements related to entrepreneurial orientation, innovation culture, develop new ideas, coordination capability, or agility. Finally, in the people capabilities dimension, we find elements related to e-literacy, data literacy, data analytics skills, or leadership and management skills.

Table 1. Open data innovation capabilities framework (adapted from Eckartz et al., 2016)

\begin{tabular}{|l|l|}
\hline \multicolumn{1}{|c|}{ Dimension } & \multicolumn{1}{c}{ Factors } \\
\hline IT capabilities & $\begin{array}{l}\text { Data governance; Data management; Interoperability; Integration of IT systems; } \\
\text { Data analytics; Data security; Data visualization; Hardware and information } \\
\text { systems; IS strategy and planning. }\end{array}$ \\
\hline $\begin{array}{l}\text { Organizational } \\
\text { capabilities }\end{array}$ & $\begin{array}{l}\text { Entrepreneurial orientation; Innovation culture; Develop new ideas; Multidisciplinary } \\
\text { teams; Agility/Flexibility to adapt; Leadership top-management support; Data-driven } \\
\text { policies (governance); Data-driven processes across the organization; Coordination } \\
\text { capability and allocation of resources. }\end{array}$ \\
\hline $\begin{array}{l}\text { People } \\
\text { capabilities }\end{array}$ & $\begin{array}{l}\text { Data analytics skills; Entrepreneurship; e-literacy; Interdisciplinary cooperation; } \\
\text { Research skills; Leadership and management skills; Data literacy; Programming } \\
\text { skills; Customer and service focus; Data visualization and reporting skills. }\end{array}$ \\
\hline
\end{tabular}

Source: own elaboration. 


\section{Results}

\section{Quantitative Analysis}

Table 2 quantitatively explores the number of projects that available in each country. This information was accounted for and aggregated from the OPSI Covid-19 Innovative Response Tracker. The level of government includes the following categories: national government (NG), local government (LG), regional government (RG), and civil society (CS). The addressed issues were composed of the following categories: real-time data collection (RDC), information and practice sharing (IPS), public service delivery (PSD), governance responses (GR), and crowdsourcing solutions (CDS). A total of 37 innovative responses were identified. South Korea and Lithuania stood out as the countries with the largest number of innovative solutions supported in open data, representing close to $30 \%$ of these solutions. Approximately 95\% of the initiatives involved local government, followed by solutions with regional and local government participation. Therefore, the role of the government in organizing and coordinating these initiatives was a common factor in the identified projects. The weight of civil society was relatively low as it appeared in only 5 out of 37 projects. However, this did not mean that civil society is uninvolved in these processes, especially in solutions involving volunteer activities. The role of the civil society focused more on the realization of these initiatives, but they presented difficulties in their autonomous organization when they were not integrated into government-funded projects. Most solutions involved realtime data collection, sharing, and analysis (e.g. 92\%), followed by information and practice sharing (e.g. 81\%). Projects were found in a wide range of areas, such as open data on Covid-19 health, open contracting approaches, open data on public services, open data for testing clinics.

Table 2. Quantitative analysis of innovative solutions

\begin{tabular}{|c|c|c|c|c|c|c|c|c|c|c|c|}
\hline \multirow{2}{*}{ Country } & \multicolumn{5}{|c|}{ Level of government } & \multicolumn{5}{|c|}{ Addressed issues } & \multirow{2}{*}{ Total } \\
\hline & NG & LG & RG & CS & PS & RDC & IPS & PSD & GVR & CDS & \\
\hline Austria & 2 & - & - & - & - & 2 & - & - & - & - & 2 \\
\hline Colombia & 1 & 1 & 1 & - & - & 1 & 1 & - & - & - & 1 \\
\hline Czech Republic & 1 & - & - & - & - & 1 & 1 & - & - & 1 & 1 \\
\hline Denmark & 1 & - & - & - & - & 1 & - & - & - & - & 1 \\
\hline Estonia & 2 & - & 2 & 1 & - & 2 & 2 & - & - & 1 & 2 \\
\hline
\end{tabular}




\begin{tabular}{|c|c|c|c|c|c|c|c|c|c|c|c|}
\hline France & 2 & 1 & 1 & 1 & - & 1 & 2 & - & - & - & 2 \\
\hline Ireland & 3 & - & 1 & 1 & - & 3 & 2 & 1 & - & - & 3 \\
\hline Israel & 2 & 1 & 1 & - & 1 & 2 & - & - & 1 & 1 & 2 \\
\hline Italy & 1 & 1 & 1 & - & - & 1 & 1 & - & 1 & - & 1 \\
\hline Japan & 1 & 1 & - & - & 1 & 1 & 1 & 1 & - & 1 & 1 \\
\hline South Korea & 6 & 2 & 2 & 1 & 1 & 6 & 6 & 4 & 2 & - & 6 \\
\hline Lithuania & 4 & 4 & 3 & - & 1 & 3 & 4 & 2 & 4 & 1 & 5 \\
\hline Mexico & 1 & 1 & 1 & - & - & 1 & 1 & - & - & - & 1 \\
\hline Netherlands & 1 & 1 & 1 & - & - & 1 & 1 & 1 & - & - & 1 \\
\hline New Zealand & 1 & 2 & 1 & - & 1 & 2 & 2 & 1 & 1 & - & 2 \\
\hline Peru & 1 & 1 & 1 & - & - & 1 & 1 & - & 1 & - & 1 \\
\hline Poland & 1 & - & - & - & - & 1 & 1 & 1 & - & - & 1 \\
\hline Portugal & 1 & 1 & 1 & - & - & 1 & 1 & - & - & - & 1 \\
\hline Slovenia & 2 & - & - & 1 & - & 2 & 2 & - & - & 1 & 2 \\
\hline United Kingdom & 1 & - & - & - & - & 1 & 1 & - & - & - & 1 \\
\hline
\end{tabular}

Source: own elaboration.

\section{Qualitative Analysis}

Next, in the qualitative analysis, I sought to identify how the innovative potential of open data is explored by each initiative considering the framework proposed by Eckartz et al. (2016) as presented in Table 3. To avoid specific and repeated information about the various projects, the initiatives were grouped by the type of project. Most of the projects referred to the provision of open datasets and data visualization dashboards.

Finally, the results of the interviews with policymakers were analyzed using thematic analysis. This approach allowed the identification of patterns in the interviews using an inductive approach, in which the categories are not predetermined, according to the approach advocated by Creswell and Poth (2017). Table 4 visualizes the results of the thematic analysis. A total of 14 themes were identified in the two interviews. The first interview allowed me to realize that the provision of a dashboard to track the evolution of Covid-19 was an initiative replicated by several countries and that it supported the development of specific regional and metropolitan policies mainly with the most vulnerable groups. Thus, open data was essential to facilitate the analysis of the data 
by research centers and universities, and it facilitated its dissemination among European partners. The second interview made it clear that most social innovation initiatives emerged before the appearance of Covid-19 in the context of the Portugal Social Innovation project. Open data is a strategy assumed by the Portuguese government that allows for the increased transparency of information and collaborative participation.

\section{Table 3. Qualitative exploration of innovative initiatives}

\begin{tabular}{|c|c|c|}
\hline Project & Country & Open data capabilities \\
\hline $\begin{array}{l}\text { Data } \\
\text { visualization } \\
\text { dashboard }\end{array}$ & $\begin{array}{l}\text { Israel, Poland, } \\
\text { Czech Republic, } \\
\text { Slovenia, Portugal, } \\
\text { New Zealand, } \\
\text { Lithuania, South Korea, } \\
\text { United Kingdom, Italy, } \\
\text { Ireland, Austria, } \\
\text { France }\end{array}$ & $\begin{array}{l}\text { The adoption of dashboards allows in a visual, easy, } \\
\text { and intuitive way to follow the evolution of the disease in } \\
\text { the country and by region. Some differences emerged between } \\
\text { the initiatives, particularly in the type of information collected, } \\
\text { such as the distribution of cases by region, by gender, } \\
\text { by symptoms recorded, by types of contagion. The role of big data } \\
\text { in IT capabilities stood out in the components of data governance, } \\
\text { data management, interoperability, and data visualization. }\end{array}$ \\
\hline Hackathons & Lithuania, Estonia & $\begin{array}{l}\text { Hackathons aim to develop technological solutions in the } \\
\text { context of the Covid-19 confrontation. This type of hackathons } \\
\text { tended to be virtual and made up of ideation, mentoring, } \\
\text { and workshop activities. The projects were evaluated following } \\
\text { a set of criteria such as the degree of innovation and creativity, } \\
\text { replicability, adherence to the objectives of sustainable } \\
\text { development, financial sustainability. Open data was used } \\
\text { to promote the development of organizational and people } \\
\text { capabilities. }\end{array}$ \\
\hline $\begin{array}{l}\text { Open } \\
\text { datasets }\end{array}$ & $\begin{array}{l}\text { Israel, Slovenia, Peru, } \\
\text { New Zealand, } \\
\text { Netherlands, Japan, } \\
\text { Mexico, Lithuania, } \\
\text { South Korea, Ireland, } \\
\text { France, Estonia, } \\
\text { Denmark, Colombia, } \\
\text { Austria }\end{array}$ & $\begin{array}{l}\text { A wide range of relevant and open data on Covid-19 were } \\
\text { publicly available, meaning not only data on the evolution of the } \\
\text { pandemic but also data on elements like health expenditures, } \\
\text { labor market, and air quality. The emphasis of open data was } \\
\text { on IT capabilities especially in terms of data analytics. }\end{array}$ \\
\hline $\begin{array}{l}\text { Services } \\
\text { availability }\end{array}$ & South Korea, Ireland & $\begin{array}{l}\text { Information about the availability of services was important } \\
\text { so that citizens could organize their daily activities and decrease } \\
\text { sources of contagion. Here, I found information about the time } \\
\text { and capacity of various services such as pharmacies, libraries, } \\
\text { or supermarkets. The focus of open data was on the customer } \\
\text { and service support component. }\end{array}$ \\
\hline $\begin{array}{l}\text { Tourism } \\
\text { information }\end{array}$ & South Korea & $\begin{array}{l}\text { Information for tourists and travelers about the evolution } \\
\text { of Covid-19 abroad. This information was relevant for citizens } \\
\text { to avoid trips to areas of greater contagion and to obtain } \\
\text { information on the contingency measures implemented by each } \\
\text { country. Moreover, in this type of project, the focus of open } \\
\text { data was on the customer and service support component. }\end{array}$ \\
\hline
\end{tabular}

Source: own elaboration. 
Table 4. Results of the thematic analysis

\begin{tabular}{|c|c|}
\hline Question & Identified themes \\
\hline \multicolumn{2}{|c|}{ Data dashboard on Covid-19 in Portugal } \\
\hline Q1: How did this initiative come about? & $\begin{array}{l}\text { Portuguese government initiative (FT1) } \\
\text { Replication in several European countries (FT2) }\end{array}$ \\
\hline Q2. What is the role of open data in this initiative? & Open access data (FT3) \\
\hline Q3. What synergies existed with other partners? & $\begin{array}{l}\text { Sharing with national and European partners (FT4) } \\
\text { R\&D centers and universities (FT5) }\end{array}$ \\
\hline Q4: What is the social relevance of this initiative? & $\begin{array}{l}\text { Support policies at regional and municipal levels } \\
\text { (FT6) } \\
\text { Follow evolution in the most socially vulnerable } \\
\text { groups (FT7) }\end{array}$ \\
\hline \multicolumn{2}{|c|}{ Shared Services Center in Portugal } \\
\hline $\begin{array}{l}\text { Q1. What is the role of government entities in } \\
\text { supporting social innovation initiatives to combat } \\
\text { Covid-19? }\end{array}$ & $\begin{array}{l}\text { Portugal Social Innovation (FT8) } \\
\text { Coordinate measures and public investment (FT9) } \\
\text { Encourage the participation of other entities } \\
\text { (FT10) }\end{array}$ \\
\hline $\begin{array}{l}\text { Q2. What is the role of open data in government } \\
\text { digitization? }\end{array}$ & $\begin{array}{l}\text { Transparency (FT11) } \\
\text { Collaborative participation (FT12) }\end{array}$ \\
\hline $\begin{array}{l}\text { Q3. What are the impacts of open data on social } \\
\text { innovation projects? }\end{array}$ & $\begin{array}{l}\text { Visibility (FT13) } \\
\text { Collaborative participation (FT14) }\end{array}$ \\
\hline
\end{tabular}

Source: own elaboration.

\section{Discussion}

Innovation as a competitive strategy is an essential factor for the development of the business ecosystem in periods of crisis (Kaszowska-Mojsa, 2020; Zak and Garncarz, 2020). Digitization was a process that was already underway in several industries but accelerated especially in companies in which processes were lagging (Marona and Tomal, 2020; Soto-Acosta, 2020). Given the Covid-19 pandemic, we observe huge demand for disruptive and entrepreneurial initiatives. After all, as Lipkind and Kitrar (2021) indicate, the current socioeconomic fragilities require quick, useful, and efficient solutions and responses, capable of ensuring our survival and adaptation to the transformations of reality. Vervoort et al. (2021) complement this view by highlighting the role of collaboration in finding innovative solutions in healthcare. However, this collaboration is not restricted to the health field but can involve other areas in society that enable innovative solutions to be found to combat the effects of Covid-19. This 
collaboration can be facilitated and enhanced using open data that allows access to a large volume of information by public and private entities and civil society.

The adoption of open data is a common practice in projects related to the provision of information to the public about Covid-19. This information is very diverse and is not restricted exclusively to presenting data on the number of dead, infected, and recovered patients. Although this information is common to all dashboards, there are also dashboards like the one in Poland - which includes information about entrepreneurs, students, and people traveling or needing social aid - or the dashboard in Lithuania, which provides detailed information about the private and public sectors most directly affected by lockdown periods. Moreover, the information included in open datasets also appears on dashboards. However, open datasets typically contain a larger set of information and allow for longitudinal studies. This data can be later treated statistically by researchers. Furthermore, the availability of these open datasets is relevant to the transparency of information on public health data, as advocated by Huston et al. (2019). Moreover, the European Public Sector Information Directive itself (DL 2013/37/EU) recognizes the importance of making data available without constraint to users.

Interoperability is another factor of great relevance that can be found in dashboards. The data available on dashboards can be extracted from different sources, typically involving several public services. Furthermore, the data is combined and used with other data or tools. As Lehne et al. (2019) argue, the data format must be open and interpretable by various tools, including other data records. Accordingly, the concept of interoperability applies to both data and metadata.

The enormous amount of data that is generated in the context of the pandemic can be useful to governments, but also to the business sector and civil society. Considering that the state is composed of various services and departments, the sharing of this data becomes a necessity. As stated by Ruijer et al. (2020), when data is open, there is the possibility of cooperation between public agencies, which enables the implementation of public policies based on evidence in the data. Moreover, open data empowers researchers to make projections and understand patterns about the spread of disease (Hahnel, 2020). This analysis is important for targeting social entrepreneurship initiatives to the most vulnerable social groups affected by the pandemic. Furthermore, the population with access to data and information can better understand the situation, gain insight into the severity of the disease or the limits of health infrastructure and bed occupancy, and can adhere more to social distancing policies. 
The national government tends to be the main driver of open data projects. This approach is followed by other government entities at regional and local levels. These solutions involve real-time data collection, sharing, and analysis, and they aim to share information and practices for the community. Civil society participation in these projects is relatively low, except for specific projects promoted by each country. These initiatives often appear in hackathons that proved to be of great importance in promoting the participation of all community actors. These kinds of initiatives demonstrate that networking - as advocated by Richterich (2019) - can help to address the challenges of a pandemic crisis. Moreover, hackathons have the collateral effect of increasing the sense of empowerment among participants as they are involved in the process of creating innovative solutions to confront the new coronavirus that would be impossible if they were to act alone.

\section{Conclusion}

Government organizations - be it national, regional, or local - employ open data to share information about Covid-19 incidence with the population and economic agents. Open and public information includes data on the effects on public health of the pandemic, but some initiatives are also complemented with information on hospital availability, pharmacy availability, and relevant information for entrepreneurs or travelers, among other things. Such information support studies of the scientific community in the public health field. When the data are open, citizens can access the data and information they seek directly on the Internet, which further contributes to increasing information transparency. Moreover, it has the side effect of freeing public organizations from the time and cost related to responding to requests for access to information.

Although most of the projects that adopt open data focus on data visualization dashboards and open datasets, there are some relevant initiatives in other fields, such as hackathons, service availability, and tourism information. This situation highlights the potential of open data as a relevant element in initiatives that involve other actors such as civil society and the private sector that also assume a relevant role in proposing innovative solutions to combat the pandemic.

This study offers both theoretical and practical implications. In the theoretical dimension, this study addresses a theme of great relevance for scientific development and in the search for responses to the pandemic that can be sufficiently comprehensive and broad. Social innovation initiatives are characterized along two dimensions: level 
of government and addressed issues. On the practical side, the analysis of the relevance and characteristics of these initiatives is important for the establishment of public policies that can promote the emergence of more social innovation initiatives and the greater involvement of partners in both the national and international context. Open data offers the potential to increase the transparency of data, the ease of sharing data, and the collaborative participation of government, private companies, and civil society. These open data initiatives are not limited to the healthcare field but address the collateral effects of Covid-19 in such areas as economy, education, or leisure.

Markedly, the above study has its limitations. First, the text does not explore the challenges posed by the relationship between transparency and privacy, a current topic of public discussion. Moreover, the article does not present how open data can be used by various platforms in big data solutions. Therefore, future studies should seek to understand how open data contributes to the emergence of innovative solutions that operate in the big data paradigm, not to mention understanding the effects of the adoption of open data in the long term, namely in a post-Covid-19 world.

\section{References}

Almeida, F. (2018). Strategies to Perform a Mixed Methods Study. European Journal of Education Studies, 5(1), 137-151.

Bittencourt, B.A., Figueiró, P.S., and Schutel, S. (2017). The Impact of Social Innovation: Benefits and Opportunities from Brazilian Social Business. Revista ESPACIOS, 38(26), 1-7.

Bornstein, D. (2007). How to Change the World: Social Entrepreneurs and the Power of New Ideas. Oxford, UK: Oxford University Press.

Chen, Y., Wang, Y., Nevo, S., Benitez-Amado, J., and Kou, G. (2015). IT capabilities and product innovation performance: The roles of corporate entrepreneurship and competitive intensity. Information $\&$ Management, 52, 643-657. https://doi.org/10.1016/j.im.2015.05.003.

Creswell, J.W., and Clarck, V.L. (2017). Designing and Conducting Mixed Methods Research. Thousand Oaks, CA: Sage Publications.

Creswell, J.W., and Poth, C.N. (2017). Qualitative Inquiry and Research Design: Choosing Among Five Approaches. Thousand Oaks, CA: Sage Publications.

Dawson, P., and Andriopoulos, C. (2017). Managing Change, Creativity and Innovation. Thousand Oaks, CA: Sage Publications.

Diepenmaat, H., Kemp, R., and Velter, M. (2020). Why Sustainable Development Requires Societal Innovation and Cannot Be Achieved without This. Sustainability, 12, 1-26.

https://doi.org/10.3390/su12031270.

EC (2021). Social innovation. Obtained from:

https://ec.europa.eu/social/main.jsp?catId=1022\&langId=en.

Fell, M.J. (2019). The Economic Impacts of Open Science: A Rapid Evidence Assessment. Publications, 7(3), 1-30. https://doi.org/10.3390/publications7030046. 
Gandhi, T., and Raina, R. (2018). Social entrepreneurship: the need, relevance, facets and constraints. Journal of Global Entrepreneurship Research, 8(9), 1-13. https://doi.org/10.1186/s40497-018-0094-6.

Goffin, K., and Mitchell, R. (2016). Innovation Management: Effective strategy and implementation. New York: Springer Publishing Company.

Grimm, R., Fox, C., Baines, S., and Albertson, K. (2013). Social innovation, an answer to contemporary societal challenges? Locating the concept in theory and practice. Innovation The European Journal of Social Science Research, 26(4), 455-463. https://doi.org/10.1080/13511610.2013.848163.

Hahnel, G.B. (2020). Research Practices in the wake of COVID-19: Busting open the myths around open data. Obtained from:

https://www.springernature.com/gp/advancing-discovery/blog/blogposts/research-practicesin-the-wake-of-covid/18256280.

Hossain, M. (2015). Crowdsourcing in business and management disciplines: an integrative literature review. Journal of Global Entrepreneurship Research, 5(21), 1-19. https://doi.org/10.1186/s40497-015-0039-2.

Huston, P., Edge, V.L., and Bernier, E. (2019). Reaping the benefits of Open Data in public health. Canada Communicable Disease Report, 45(11), 252-256. https://doi.org/10.14745/ccdr.v45i10a01.

Ismail, K., Sohel, M.H., and Ayuniza, U.N. (2012). Technology social venture: A new genre of social entrepreneurship? Procedia - Social and Behavioral Sciences, 40, 429-434. https://doi.org/10.1016/j.sbspro.2012.03.211.

Javed, A., Yasir, M., and Majid, A. (2019). Is social entrepreneurship a panacea for sustainable enterprise development? Pakistan Journal of Commerce and Social Sciences (PJCSS), 13(1), 1-29.

Johnson, M.P., and Schaltegger, S. (2019). Entrepreneurship for Sustainable Development: A Review and Multilevel Causal Mechanism Framework. Entrepreneurship Theory and Practice, 44(6), 1141-1173. https://doi.org/10.1177/1042258719885368.

Kaszowska-Mojsa, J. (2020). Innovation strategies of manufacturing companies during expansions and slowdowns. Entrepreneurial Business and Economics Review, 8(4), 4-66. https://doi.org/10.15678/EBER.2020.080403.

Lehne, M., Sass, J., Essenwanger, A., Schepers, J., and Thun, S. (2019). Why digital medicine depends on interoperability. NPJ Digital Medicine, 2(79), 1-5. https://doi.org/10.1038/s41746-019-0158-1.

Lipkind, T., and Kitrar, L. (2021). The impact of aggregate business and household behaviour on economic growth: an emphasis on the corona crisis. Entrepreneurial Business and Economics Review, in press.

Marona, B., and Tomal, M. (2020). The COVID-19 pandemic impact upon housing brokers' workflow and their clients' attitude: Real estate market in Krakow. Entrepreneurial Business and Economics Review, 8(4), 221-232. https://doi.org/10.15678/EBER.2020.080412.

Montgomery, A.W., Dacin, P.A., and Dacin, M.T. (2012). Collective Social Entrepreneurship: Collaboratively Shaping Social Good. Journal of Business Ethics, 111, 375-388. https://doi.org/10.1007/s10551-012-1501-5.

Muñiz-Avila, E., Rodríguez-Aceves, L., and Flores-Castro, M.A. (2016). Implementation of a Social Innovation Model for Economic Value Creation. In: J.M. Saiz-Álvarez (ed.) Handbook of Research on Social Entrepreneurship and Solidarity Economics (pp. 111-133). Hersehy, PA: IGI Global. https://doi.org/10.4018/978-1-5225-0097-1.ch007.

Musa, E. (2019). Crowdsourcing Social Innovation: Towards a Collaborative Social Capitalism. In: Social Entrepreneurship: Concepts, Methodologies, Tools, and Applications (pp. 83-106). Hershey: PA: IGI Global. https://doi.org/10.4018/978-1-5225-8182-6.ch005. 
Neto, J.C., Filipe, J.A., and Caleiro, A.B. (2019). Creativity and innovation: A contribution of behavioral economics. International Journal of Innovation Studies, 3(1), 12-21. https://doi.org/10.1016/j.ijis.2019.06.003.

Nga, J.K., Prialé, M.A., Darmohraj, A., Moschetti, M., Fuchs, R.M., and Sáenz, M. (2018). Personality Traits and Social Entrepreneurship Dimensions in Peru and Argentina. Compendium, 5(11), 120-143.

Ngatse-Ipangui, R., and Dassah, M. (2019). Impact of social entrepreneurs on community development in the Cape Town Metropolitan Municipality area, South Africa. The Journal for Transdisciplinary Research in Southern Africa, 15(1), 1-10. https://doi.org/10.4102/td.v15i1.474.

Nicholls A., Simon J., and Gabriel, M. (2015). Introduction: Dimensions of Social Innovation. In: A. Nicholls, J. Simon, M. Gabriel (eds.), New Frontiers in Social Innovation Research (pp. 1-26). London, UK: Palgrave Macmillan. https://doi.org/10.1057/9781137506801_1.

Nicola, M., Alsafi, Z., Sohrabi, C., Kerwan, A., Al-Jabir, A., Iosifidis, C., Agha, M., and Agha, R. (2020). The socio-economic implications of the coronavirus pandemic (COVID-19): A review. International Journal of Surgery, 78, 185-193.

OECD (2019). Development of Public Sector Innovation Observatory. Obtained from: https://cordis.europa.eu/project/id/671526/reporting.

Ormiston, J., and Seymour, R. (2011). Understanding Value Creation in Social Entrepreneurship: The Importance of Aligning Mission, Strategy and Impact Measurement. Journal of Social Entrepreneurship, 2(2), 125-150. https://doi.org/10.1080/19420676.2011.606331.

Parente, C., Lopes, A., and Marcos, V. (2013). Social Entrepreneurship Profiles: Lessons from Organizational and Management Dynamics. Journal of Social Entrepreneurship, 5(1), 22-41. https://doi.org/10.1080/19420676.2013.820782.

Pawar, M. (2020). The Global Impact of and Responses to the COVID-19 Pandemic. The International Journal of Community and Social Development, 2(2), 111-120. https://doi.org/10.1177/2516602620938542.

Petrella, F., and Richez-Battesti, N. (2014). Social entrepreneur, social entrepreneurship and social enterprise: semantics and controversies. Journal of Innovation Economics \& Management, 2(14), 143-156. https://doi.org/10.3917/jie.014.0143.

Polyakova, M., Kocks, G., Udalova, V., and Finkelstein, A. (2020). Initial economic damage from the COVID-19 pandemic in the United States is more widespread across ages and geographies than initial mortality impacts. Proceedings of the National Academy of Sciences, 117(45), 27934-27939. https://doi.org/10.1073/pnas.2014279117.

Richterich, A. (2019). Hacking events: Project development practices and technology use at hackathons. Convergence: The International Journal of Research into New Media Technologies, 25(5-6), 1000-1026. https://doi.org/10.1177/1354856517709405.

Roper, S., and Turner, J. (2020). R\&D and innovation after COVID-19: What can we expect? A review of prior research and data trends after the great financial crisis. International Small Business Journal: Researching Entrepreneurship, 38(6), 504-514. https://doi.org/10.1177/0266242620947946.

Ruijer, E., Détienne, F., Baker, M., Groff, J., and Meijer, A.J. (2020). The Politics of Open Government Data: Understanding Organizational Responses to Pressure for More Transparency. The American Review of Public Administration, 50(3), 260-274. https://doi.org/10.1177/0275074019888065.

Ruijer, E., and Meijer, A. (2020). Open Government Data as an Innovation Process: Lessons from a Living Lab Experiment. Public Performance \& Management Review, 43(3), 613-635. https://doi.org/10.1080/15309576.2019.1568884.

Saebi, T., Foss, N. J., and Linder, S. (2019). Social Entrepreneurship Research: Past Achievements and Future Promises. Journal of Management, 45(1), 70-95. https://doi.org/10.1177/0149206318793196. 
Soto-Acosta, P. (2020). COVID-19 Pandemic: Shifting Digital Transformation to a High-Speed Gear. Information Systems Management, 37(4), 260-266. https://doi.org/10.1080/10580530.2020.1814461.

Tello-Rozas, S. (2016). Inclusive Innovations Through Social and Solidarity Economy Initiatives: A Process Analysis of a Peruvian Case Study. VOLUNTAS: International Journal of Voluntary and Nonprofit Organizations, 27, 61-85. https://doi.org/10.1007/s11266-015-9606-y.

Vervoort, D., Ma, X., and Luc, JY. (2021). COVID-19 pandemic: a time for collaboration and a unified global health front. International Journal for Quality in Health Care, 33(1), 1-3. https://doi.org/10.1093/intqhc/mzaa065.

Witkamp, M.J., Raven, R., and Royakkers, L. (2011). Strategic niche management of social innovations: the case of social entrepreneurship. Technology Analysis \& Strategic Management, 23(6), 667-681. https://doi.org/10.1080/09537325.2011.585035.

Zak, M., and Garncarz, J. (2020). Economic policy towards the challenges of the COVID-19 pandemic in selected European Union countries. International Entrepreneurship Review, 6(4), 21-34. https://doi.org/10.15678/IER.2020.0604.02nal Entrepreneurship Review, 6(4), 21-34. 